\title{
On the Strategies of Enhancing Students' Cultural Awareness in College English Teaching
}

\author{
Guoqiao Wang ${ }^{1}$ \\ ${ }^{1}$ English Department, North China Electric Power University, Baoding City, Hebei Province, China \\ Correspondence: Guoqiao Wang, English Department, North China Electric Power University, Baoding City, \\ Hebei Province, China.
}

Received: September 14, 2018

Accepted: November 15, 2018 Online Published: November 19, 2018

doi: $10.5539 /$ elt.v11n12p116

URL: https://doi.org/10.5539/elt.v11n12p116

\begin{abstract}
Lack of cultural awareness and insufficient cultural background knowledge directly obstruct students' learning competence in college English teaching. Therefore, it's of great importance to enhance students' cultural awareness and develop their background knowledge about the target culture. This paper intends to illustrate the influence of cultural background knowledge deficiency on English learning, analyze the possible causes of students' lack of cultural background knowledge, and suggest approaches to enriching students' background knowledge of the target culture.
\end{abstract}

Keywords: cultural awareness, strategies, enhance, cultural background knowledge, college English teaching

\section{Introduction}

College English Teaching in China has undergone a lot of hardships and has obtained remarkable progress. However, further improvement and reform need to be made in the teaching practice. English teachers should strive hard to cultivate and develop students' linguistic competence by means of practicing listening, speaking, reading, writing and translating as well. To cultivate and promote students' out-put competence of the language, the in-put knowledge should be stressed and enhanced. Factors directly influencing students' linguistic competence are limited vocabulary, unfamiliar grammar, complicated sentence structures and the ability to comprehend, analyze, make inferences. And what's more, students' knowledge about the culture of the target language also plays a very important role in their comprehension competence. When the reading or listening material is related to a foreign culture with its traditions, customs and historical events unknown to the students, they may find it really difficult to get a clear and accurate understanding of the material, even though the verbal barriers are few. Therefore, students' cultural awareness influences their linguistic competence to a large extent. Students' cultural awareness should be emphasized and enhanced in college English teaching.

Language of a nation has emerged and developed in long subsistence with the nation. Anything and everything of its culture is reflected in the language. And language is just like a mirror that reflects its national culture. As language is the carrier of the culture, the culture attaches itself to the language. The usage of language cannot exist outside of a certain society or social culture. Hence the teaching of culture forms an important aspect in college English teaching. The learning of cultural background knowledge should never be ignored or omitted in second language acquisition. Unfamiliarity with the culture of the target language may seriously obstructs students' comprehension competence. So students' cultural awareness needs to be enhanced to improve their linguistic competence.

\section{The Significance of Enhancing Students' Cultural Awareness}

Cultural awareness directly influences students' linguistic competence to a large extent. It's of great significance to enhance students' cultural awareness so as to cultivate and improve their linguistic competence. The lack of cross-cultural awareness and insufficient cultural background knowledge interfere with students' thorough understanding of the reading materials they are working at. In English learning, students need to do a large amount of reading practice to improve their reading ability. So innumerous reading materials are presented to the students. Articles both in the textbooks and in the supplementary materials are original ones written by native English speakers. And these articles cover a wide range of subjects and rich in content. Inevitably, they involve the particular and rich culture of the English-speaking countries and reflect their customs, traditions, history, 
economy, politics, religious beliefs and so forth. As is known to everyone, language is the expression of the ideas of the society and culture is what the society thinks and does, we can draw a conclusion that language is actually one expression of the culture. So in college English teaching, it's far from enough just to focus on linguistic knowledge such as vocabulary, grammar, sentence structure, textual structure. The knowledge about target language culture should be infiltrated in the process of language teaching.

The role of cultural background knowledge in language comprehension has been formalized as schema theory (Carrell, 1983). According to this theory, comprehending a text is an interactive process between the reader's background knowledge and the text. Efficient comprehension requires the reader's ability to relate the textual material to his own knowledge. And it involves more than his linguistic knowledge. The non-linguistic elements such as the background knowledge about target culture are also essential to accurate and efficient comprehension of the reading materials. The lack of cultural background knowledge will render the comprehension difficult or even impossible.

For instance, in Unit 3 "Why I teach" taken from College English Intensive Reading Book Three, there is such a sentf this cultural element and know nothing about the Bible, they will find this sentence unintelligible and puzzling, thus unable to understand its meaning. We know that Bible is a very important component of the western culture and it has immeasurable influence on the art, culture, ideology and politics of the western society. Many artists and writers found their inspirations in the Bible. A large majority of the English literary works quote the names, places or allusions from the Bible. Some people even say that you cannot understand the western culture if you have never read the Bible. So it's necessary to provide the students with the needed cultural background knowledgeence: "Being a teacher is being present at the creation, when the clay begins to breathe." If the students are not aware o about the Bible so that they can have a clear and complete comprehension of this sentence. According to the Bible, man was created by God out of clay. When God breathed the breath of life into the nostrils of the clay, it became alive and the creation of man was completed. Here the author appropriately quotes this allusion from the Bible and compares the job of a teacher to the work of God. What this sentence implies is that while the parents give the student the body, it is the teacher who helps to mould his character and helps the student become a real man or woman. Only through the explanation of the cultural knowledge involved here can the students really understand the implied meaning of the sentence. Therefore, teachers should strive to find effective strategies to enhance students' cultural awareness in order to render them sensitive to such cultural elements.

\section{Causes of Students' Lack of Cultural Background Knowledge}

Language is a symbolic product of the progress of the human society and human civilization. Different languages have different history of development. The origin and development of English is obviously different from that of our native language - Chinese. And language is the carrier of culture. The arts, literature, science, laws, economic systems and religions of the world can not exist without language. So language is inseparable from culture and it reflects the culture of the countries where this language is spoken as native. Therefore, if we want to learn the language of a foreign country, it's necessary for us to learn its culture. From the socio-linguistic perspective, a language should be learnt as it is used by its people. In other words, it should not be learnt in isolation from its social context. "Culture is the context within which we exist, think, feel, and relate to others" (Brown, 1980). Therefore, the teaching of culture should be emphasized and reinforced in college English teaching.

However, in the teaching practice, much of the attention and interest has long been focused on the system of the language itself. For a long time, our teaching and learning of foreign languages has emphasized only verbal usage, and not associated cultural sensitivities. In English classes, most stress and attention are paid to linguistic knowledge such as vocabulary, set phrases, grammar, sentence structure etc. An introduction to the target culture, like social customs, religions and history, is seldom included in English classes. And this is due to the misunderstanding of English learning and teaching - linguistic knowledge is always emphasized while cultural knowledge is often neglected. We teach English not just to impart the verbal knowledge to students. What's more important, English is taught and learned for the purpose of communication. To communicate with native English speakers, we, as non-native speakers, need to know their culture. Otherwise the culture shock may well render us bewildered or embarrassed. However we Chinese have few chances of accessing the culture of the English-speaking countries. Hence it seems to be natural that students lack enough background knowledge about the culture of the target language as they are not brought up in that foreign civilization.

Students' lack of cultural background knowledge is partly because our teachers are not aware that language learning should develop not only the students' language skills but also their cultural knowledge, and partly 
because teachers themselves are not familiar with Western culture, having insufficient knowledge in this aspect when at school and few opportunities to go abroad, limiting their awareness of culture. If the teachers themselves cannot notice the cultural elements embodied in the texts being studied, how can they be expected to alert students to them? For instance, in College English Book Three Unit One A Brush With the Law, there is a sentence going like this: "At the time I was nineteen, had long untidy hair, and regarded myself as part of the sixties' youth counterculture." If the teacher isn't aware of the cultural element "the sixties' youth counterculture", this phrase may go unexplained and leave the students puzzled, wondering what is the sixties' youth counterculture. On the contrary, if the teacher knows it very well and clearly elaborates it, the students will be able to understand this sentence much better and their cultural background knowledge can be enriched. The background information here is like this: The word "counterculture" was coined in the 1960s for the attitude and life style of many young people who rejected conventional social values and demanded more personal freedom. The counterculture first arose in the U.S. during the 1960s and soon spread to Britain, France and other western countries. These young people were opposed to the Vietnam War and dissatisfied with the existing state of affairs in their society. Yet, unable to find a more constructive way of struggling against these, they indulged themselves in sex, drugs, alcohol and rock music and took great pride in wearing long hair and unusual clothes and in taking up anything that was unconventional. And they are known as the Hippies. The counterculture declined in the late 1970s. Not only can such background knowledge help students understand the text but also can arouse their interest in English study and the culture of English-speaking countries. Therefore teachers should be sensitive to the cultural elements in the teaching materials and furnish themselves with the most possibly rich cultural background knowledge.

From the above discussion, it can be concluded that the introduction of cultural background knowledge should be emphasized in the course of college English teaching. The goal is to achieve students' awareness of cultural elements so that they can compare the foreign culture with their own culture to understand the intercultural differences. The more cultural knowledge the students acquire, the fewer barriers they will confront in language learning.

\section{Strategies of Enhancing Students' Cultural Awareness}

In order to enhance students' cultural awareness, teachers should seize every opportunity to teach and explain cultural knowledge in the college English teaching practice. Teachers have the duty to propagate the culture of the target language while teaching students linguistic knowledge. So first of all, teachers should be well learned in the target culture. And they should strive to be bicultural. They should be aware of the existence of the different cultures and become knowledgeable in the target culture. For English teachers, English is also a foreign language. Therefore teachers should keep learning to make themselves familiar with the target culture. They should use every means available to enrich their knowledge of the country and the people and familiarize themselves with the customs and habits, history, religion and beliefs, social values and so forth. And in the teaching process, they should consciously reflect and analyze different and contrastive cultural facts so as to enhance students' cultural awareness.

The strategy of introduction and explanation makes a feasible and efficient way to enrich the students' cultural knowledge. In the process of teaching, teachers can apply this strategy to introduce the cultural background knowledge related with the teaching materials, especially the basic and major cultural knowledge which represents and reflects the major features of the target culture. Teachers had better make the best use of classroom teaching to introduce the target culture. It's a direct and quick way for students to accumulate basic and necessary cultural knowledge. For example, in College English Extensive Reading Book One Unit Four there is an article entitled The Garden of Eden which is a famous story from the Bible. It is not only a sacred book but also important literature and a source of literary inspiration. Many great writers, poets and painters created masterpieces based on the Bible and its stories. Teachers should take this opportunity to introduce the Bible to the students and provide them with the necessary information about the Bible. The Bible is composed of two main parts: the Old Testament and the New Testament. The Old Testament is traditionally divided into three parts: the Law, the Prophets and the Writings. Christianity regards the Old Testament as an accurate record of God's dealings with His people in preparation for the coming of Jesus Christ, containing much New Testament teaching at its early stage of development. The New Testament is concerned with the life and teaching of Jesus Christ and his earliest followers. Teachers may ask the students to name the Bible stories they have ever read. The following well-known Bible stories can be recommended to the students: The Garden of Eden, Noah's Ark, The Prodigal Son, The Last Supper, The Death of Jesus, etc. The Bible has exerted an incalculable influence on the thought, attitudes, beliefs, art, science, and politics of Western society. The Bible makes an essential and necessary part in the introduction of the Western culture. By means of such introduction and explanation, 
students' knowledge about the target culture can be directly and efficiently enriched.

In classroom teaching, the strategy of cross-cultural comparison can also be applied to introduce the target culture. And this strategy has proven to be very important and effective in cross-cultural language teaching. As the saying goes, only by comparing can one distinguish. The cross-cultural comparison can help the students identify and understand the cultural elements involved in what they are reading. Due to their different history and different tradition, people of different culture follow different customs. Every country has its long-established beliefs and religion, which enormously influences its people's mode of thinking and concept of value. For instance, modesty, senior citizens or the right of the group are put in a top place in China. By contrast, personality and independence are the aim of English native speakers. And in daily life English native speakers may hug each other when meeting while the Chinese shake hands. The English speakers are inclined to thank others to their face and take praises naturally. And they tend to open the gift box in the presence of those who give it. However this may be regarded as impolite and improper in China. In College English Intensive Reading Book One Unit Five, the text entitled "A Miserable, Merry Christmas". Before the text analysis, the teacher can take the opportunity to introduce some cultural background knowledge about Christmas. The introduction may include the origin of Christmas, the custom of its celebration, Santa Claus, Christmas shopping, Christmas presents, Christmas songs etc. Then the teacher can make a comparison between Christmas in Western culture and the spring festival in China. The comparison may include the similarities and differences in their origin, the way of celebration, the dinner party, their significances etc. Students are encouraged to speak out what they know about the two different holidays. Therefore, through comparison between the target culture and our own culture, students can learn more about the target culture and be better at sensing and understanding the cultural items they may encounter in reading. And in the teaching practice, teachers should remind students to keep in mind a kind of cultural sensitivity, both of their own culture and of the target culture.

In addition, extensive reading is believed to be another effective strategy for students to learn about and accumulate background knowledge about the target culture. The time spent on classroom teaching is undoubtedly limited and far from being enough. In order to gain maximum access to the target culture with real-life situations and natural life-like communication, it is necessary to select supplementary cultural materials from available authentic sources. Teachers should select appropriate reading materials to enrich students' cultural knowledge. Students' reading competence and their cultural knowledge reinforce each other. Cultural background knowledge directly influences students' reading comprehension competence. While reading comprehension practice can, in turn, increase and enrich students' cultural background knowledge. Students' lack of sufficient cultural background knowledge is partly attributed to their limited amount of extensive reading. Therefore, the role of extensive reading after class should be stressed. Students should be encouraged and motivated to read extensively after class. It has proved useful and helpful for students to make the best use of some relatively good materials available to them. So choosing relevant materials containing cultural aspects of the target language is also of essential importance. Among the prior choice are books directly introducing the background knowledge about the target culture and literary books which reflect the cultural traits such as novels, plays, poems, short stories, newspapers, magazines etc. As a learner of English who has never resided in the target language culture, gaining from books some second-hand knowledge of such things as British or American geography, history, politics, values, customs and festivals, is still quite beneficial. The writers endeavored to put what they considered important aspects of culture in a suitable way, and at the same time consciously or unconsciously transmit the views, values, beliefs, attitudes and feelings of their own English-speaking countries, which can also help students to know their culture from various angles.

The last but not the least, mass media, such as TV and radio broadcasting, movies, newspapers, and the popular internet etc. are also considered an insightful means of obtaining cultural knowledge, for they reflect people's way of life in terms of variety, contemporaneousness and authenticity. The audio-visual media materials and approaches are especially welcome and beneficial due to their vivid presentation of both language and cultural knowledge based on authentic circumstances. These modern teaching facilities supported by modern technology can bring in cultural input in a clear and realistic way compared with the traditional chalk and blackboard teaching method. Multi-media technology brings convenience and opportunity to college English teaching and offers an easy access to learning about the target culture. It is generally agreed that what helps in cultural acquisition is first and foremost personal contact with native speakers, followed by access to audio-video materials such as films and videotapes. Therefore, if possible, students should enjoy more opportunities to appreciate English movies, or watch TV for English news or English programs, or listen to the radio for English broadcasting etc. 


\section{Conclusion}

To sum up, the lack of cultural awareness and insufficient background knowledge directly hinder students' comprehension and linguistic competence to a large extent. In order to improve students' linguistic competence, their cultural awareness needs to be enhanced urgently. The teaching of culture should be put emphasis on in college English teaching. Teachers should endeavor to explore and apply various effective strategies to enrich students' cultural background knowledge. Neither teachers nor students should focus on linguistic knowledge only. The teaching and learning of the target culture is necessary and significant in college English teaching. Students are advised to make the best use of the educational resources available to them in order to gain and increase their cultural knowledge. Only with the collaborative efforts of teachers and students can our students be well cultivated both in language and culture and have a good command of English.

\section{References}

Hu, W. Z. (1995). A Dictionary of British and American Culture. Beijing: Foreign Language Teaching and Research Press.

Liu, J. (2017). The Applicatin Research on the Introduction of Cross-cultural Awareness in High School English Reading Teaching. (Master dissertation). Bohai University, Jinzhou City, Liaoning Province, China. http://cdmd.cnki.com.cn/Article/CDMD-10167-1017197891.htm

Ron, S., \& Suzanne, W. S. (2000). Intercultural Communication: A Discourse Approach. Beijing: Foreign Language Teaching and Research Press.

Tian, Y. M. (2003). Increasing cross-cultural awareness in EFL teaching and learning (pp. 41-44). English Teaching \& Research Notes in Normal School.

Wang, D. (2014). The Cultivation of the Cultural-awareness in College English Teaching (pp. 37-53). Science \& Technology Vision.

Wen, C., Vivian, W., Michael, M., \& Nian-Shing, C. (2013). Assessing cultural awareness and linguistic competency of EFL learners in a CMC-based active learning context (pp. 515-528). Elsevierjournal, Elsevier Ltd.

Yan, J. L. (2001). Culture: what to teach and how to teach it in an EFL class (pp. 21-24). Teaching English in China.

Zhao, Y. B. (1996,). Increasing learners' cultural awareness (pp. 63-66). Teaching English in China.

\section{Copyrights}

Copyright for this article is retained by the author(s), with first publication rights granted to the journal.

This is an open-access article distributed under the terms and conditions of the Creative Commons Attribution license (http://creativecommons.org/licenses/by/4.0/). 